\title{
Maintenance of spermiogenesis by exogenous testosterone in rats treated with a GnRH antagonist: relationship with androgen-binding protein status
}

\author{
L. Pogach ${ }^{1,2}$, W. Giglio ${ }^{1}$, E. Nathan ${ }^{1}$ and H. F. S. Huang ${ }^{1,3}$ \\ ${ }^{1}$ Department of Medicine (111), Department of Veterans Affairs Medical Center, East Orange, \\ NJ 07018, USA; ${ }^{2}$ Department of Medicine and ${ }^{3}$ Section of Urology, UMDNJ-New Jersey Medical \\ School, 185 South Orange Avenue, Newark, NJ 07103, USA
}

The relationship of the testicular distribution and $\left[{ }^{3} \mathrm{H}\right]$ dihydrotestosterone-binding capacity of androgen-binding protein (ABP) to the completion of spermiogenesis was examined in mature rats given daily injections of 25 or $250 \mu \mathrm{g} \mathrm{kg}^{-1}$ body weight of $\mathrm{GnRH}$ antagonist (GnRH-A; Ac-D $\{2\}, \mathrm{Nal}^{1}, 4 \mathrm{Cl}-\mathrm{D}, \mathrm{Phe}^{2}, \mathrm{D}-\mathrm{Trp}^{3}, \mathrm{D}-\mathrm{Arg}^{6}, \mathrm{D}-\mathrm{Ala}^{10}$ ) for two weeks with or without subcutaneous implantation of $10 \mathrm{~cm}$ testosterone capsules. $\mathrm{GnRH}-\mathrm{A}$ administration resulted in a dose-dependent suppression of serum FSH, which was partially prevented in the $250 \mu \mathrm{g} \mathrm{GnRH}-\mathrm{A} \mathrm{kg}^{-1}$ group by exogenous testosterone. The total testicular testosterone content and concentration of testosterone in seminiferous tubular fluid were equally suppressed in both groups of rats treated with GnRH-A and receiving the testosterone supplement. $\mathrm{ABP}$ concentrations in interstitial and seminiferous tubular fluid were normal in rats given the $25 \mu \mathrm{g} \mathrm{GnRH}-\mathrm{A} \mathrm{kg}^{-1}$ dose, and were increased $(P<0.05)$ by concomitant testosterone treatment. In contrast, $\mathrm{ABP}$ concentrations in interstitial and seminiferous tubular fluid were increased in rats given the $250 \mu \mathrm{g}$ GnRH-A kg ${ }^{-1}$ dose. This effect was attenuated when exogenous testosterone was given. Although binding of $\left[{ }^{3} \mathrm{H}\right]$ dihydrotestosterone by $\mathrm{ABP}$ in seminiferous tubular fluid was not affected by GnRH-A treatment, with or without exogenous testosterone, it was reduced in interstitial fluid by GnRH-A in a dose-dependent manner, and partially restored by testosterone administration. While complete spermatogenesis was maintained in rats given $25 \mu \mathrm{g} \mathrm{GnRH}-\mathrm{A} \mathrm{kg}^{-1}$, the number of step 7 and step 19 spermatids were both reduced by $35 \%$, and were not affected by testosterone implants. However, administration of $250 \mu \mathrm{g} \mathrm{GnRH}-\mathrm{A} \mathrm{kg}^{-1}$ injections resulted in a $60 \%$ and $90 \%$ reduction of step 7 and step 19 spermatids, respectively. Administration of exogenous testosterone greatly increased the number of step 19 spermatids. This finding was associated with partial normalization of serum $\mathrm{FSH}$, and $\left[{ }^{3} \mathrm{H}\right]$ dihydrotestosterone-binding by $\mathrm{ABP}$ in interstitial fluid, without changes in testicular testosterone. These results suggest that the bioavailability of ABP within the testis may be critical for the final steps of spermiogenesis.

\section{Introduction}

Although the effectiveness of exogenous testosterone in the maintenance of normal spermatogenesis in rats administered GnRH antagonist (GnRH-A) has been reported (Rea et al., 1986; Bhasin et al., 1987), the mechanisms by which androgens exert this effect remain undefined. Suppression of intratesticular testosterone frequently results in the disruption of normal spermiogenesis (Russell and Clermont, 1977; Huang and Boccabella, 1988), but qualitatively normal spermatogenesis can be maintained in the presence of $15-20 \%$ of normal testosterone concentration in testes in intact rats (Cunningham and Huckins, 1979; Huang and Nieschlag, 1986; Zirkin et al., 1989), as well as in hypophysectomized animals (Huang et al., 1987; Santulli et al., 1990). These observations suggest that the differentiation of spermatids during the second half of

Received 27 July 1992. spermiogenesis may involve specific local mechanisms that are not directly related to testosterone concentration.

We have recently noted that the impairment of spermiogenesis following the administration of a GnRH-antagonist (GnRH-A) was associated with a significant decline in epididymal androgen-binding protein (ABP) content while testicular $\mathrm{ABP}$ content and serum $\mathrm{ABP}$ concentration increased (Huang et al., 1992). Furthermore, enhancement of the testosterone maintenance of spermatogenesis in hypophysectomized rats by FSH was associated with an increase in testicular testosterone and $\mathrm{ABP}$ content, as well as epididymal $\mathrm{ABP}$ content (Huang et al., 1991). These results suggest that ABP distribution within the testis, the transport of $A B P$ to the epididymis, or both factors, may be important in the completion of spermiogenesis.

The present study examined ABP distribution and $\left[{ }^{3} \mathrm{H}\right]$ dihydrotestosterone (DHT)-binding activity in the testis, and its content in the epididymis in rats treated with GnRH-A, 
Table 1. Effects of testosterone implants on the organ weights of rats treated with $\mathrm{GnRH}$ antagonist (GnRH-A)

\begin{tabular}{lccccc}
\hline Treatment & $n$ & $\begin{array}{c}\text { Testis } \\
(\mathrm{mg})\end{array}$ & $\begin{array}{c}\text { Epididymis } \\
(\mathrm{mg})\end{array}$ & $\begin{array}{c}\text { Seminal vesicle } \\
(\mathrm{mg})\end{array}$ & $\begin{array}{c}\text { Pituitary } \\
(\mathrm{mg})\end{array}$ \\
\hline Control & 6 & $1626 \pm 30$ & $498 \pm 30$ & $1361 \pm 63$ & $11.8 \pm 0.5$ \\
$\begin{array}{l}\text { GnRH-A }\left(\mu \mathrm{g} \mathrm{kg}^{-1}\right) \\
\quad 65\end{array}$ & 6 & $1486 \pm 41$ & $475 \pm 12$ & $1097 \pm 65^{\mathrm{a}}$ & $11.4 \pm 0.5$ \\
$\quad 25$ plus testosterone & 5 & $1521 \pm 50$ & $488 \pm 17$ & $2006 \pm 98^{\mathrm{ab}}$ & $11.4 \pm 0.4$ \\
250 & 6 & $1001 \pm 128^{\mathrm{a}}$ & $204 \pm 24^{\mathrm{a}}$ & $156 \pm 15^{\mathrm{a}}$ & $9.8 \pm 0.5^{\mathrm{a}}$ \\
250 plus testosterone & 6 & $1503 \pm 46^{\mathrm{b}}$ & $469 \pm 15^{\mathrm{b}}$ & $2155 \pm 109^{\mathrm{ab}}$ & $8.9 \pm 0.6^{\mathrm{a}}$ \\
\hline
\end{tabular}

Values are means \pm SEM

${ }^{a}$ Significantly different from control $(P<0.05)$.

bEffect of testosterone implant was significant $(P<0.05)$
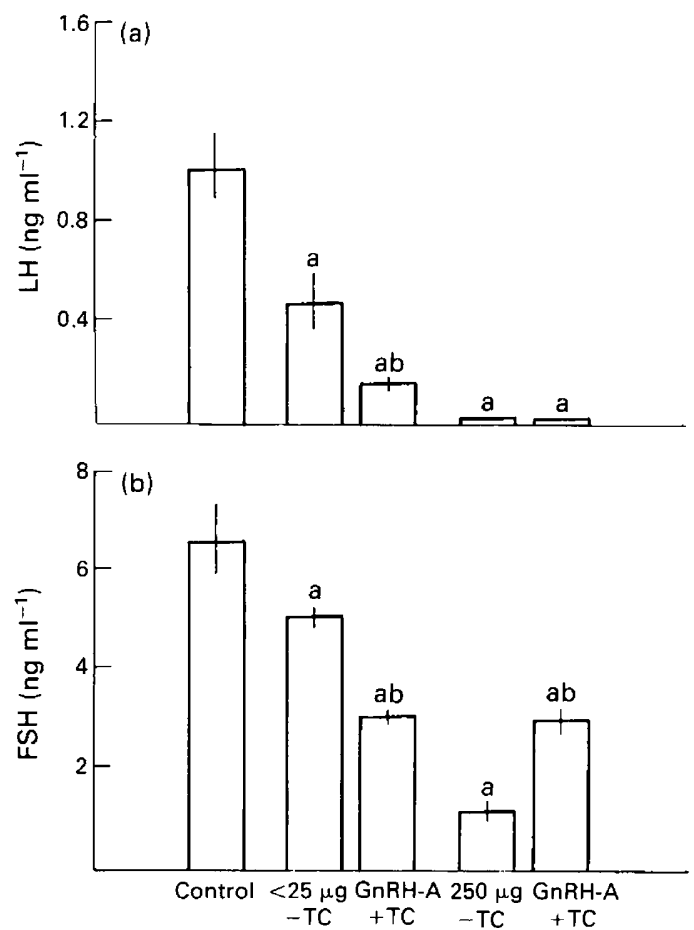

Fig. 1. Serum (a) LH and (b) FSH responses in rats receiving daily injections of 25 or $250 \mu \mathrm{g} \mathrm{GnRH-A} \mathrm{kg}{ }^{-1}$ with $(+\mathrm{TC})$ or without (-TC) $10 \mathrm{~cm}$ testosterone capsule implants for 2 weeks. Results are expressed as mean \pm SEM $\mathrm{ng}$ hormone per $\mathrm{ml}^{-1}$ serum. ${ }^{\text {aS }}$ ignificantly different from control $(P<0.05)$; ${ }^{b}$ effect of testosterone treatment significant compared with GnRH-A alone $(P<0.05) . n=5$ or 6 rats.

with or without testosterone supplement, and their relationship with the maintenance of spermiogenesis.

\section{Materials and Methods}

\section{Treatment of animals}

Mature Sprague-Dawley male rats $(250-275 \mathrm{~g})$ were randomly assigned to receive a daily subcutaneous injection of
25 or $250 \mu \mathrm{g}$ GnRH-A kg ${ }^{-1}$ (Ac-D $\{2\}, \mathrm{Nal}^{1}, 4 \mathrm{Cl}-\mathrm{D}, \mathrm{Phe}^{2}, \mathrm{D}-$ $\left.\mathrm{Trp}^{3}, \mathrm{D}-\mathrm{Arg}^{6}, \mathrm{D}-\mathrm{Ala}^{10}\right)$ for 2 weeks. Half of the animals of each group received s.c. implants of $10 \mathrm{~cm}$ testosterone capsules immediately after the first GnRH-A injection. Control animals were given a daily injection of $0.1 \mathrm{ml}$ autoclaved water. Throughout the experiment, animals were in cages in an airconditioned, light-controlled animal room and were fed Purina rat chow and water ad libitum.

At the end of the treatment period, animals were lightly anaesthetized with ether and 3-4 ml of retro-orbital sinus blood was collected from each animal. Animals were subsequently killed by an overdose of ether. One testis from each animal was used immediately for the collection of interstitial fluid and seminiferous tubular fluid as described by Turner et al. (1984). The epididymides were stored at $-70^{\circ} \mathrm{C}$ for subsequent measurement of androgen-binding protein. The other testis was fixed in Bouin's solution and processed for histology.

\section{Spermatogenesis}

Paraffin sections were stained with periodic acid-Schiff's (PAS) reagent and counterstained with haematoxylin (Pearse, 1968). The stages of the seminiferous epithelium were determined by the development of the PAS-positive acrosome of spermatids (LeBlond and Clermont, 1952). The number of step 7 and 18-19 spermatids was determined in 15-20 crosssections of stage VII seminiferous tubules and the result was expressed as the number of cells per 100 Sertoli cell nuclei.

\section{Hormone measurement}

Serum FSH and LH were determined by double antibody radioimmunoassay as described by Pogach et al. (1988). Reagents provided by NIADDK (Bethesda, MD), rat FSH-RP-2, rat FSH-I-5 and anti-rat FSH-S-11, and rat LH-RP-2, rat LH-I-6 and anti-rat LH-S-7 were used for FSH and LH assay, respectively. The sensitivity ( $90 \%$ binding) of the assay was 2.6 and $0.21 \mathrm{ng} \mathrm{ml}^{-1}$ for FSH and $\mathrm{LH}$, respectively. The intra and interassay coefficients of variation were approximately $8 \%$ and $12 \%$, respectively, for both assays. 
Table 2. Distribution of testosterone in serum and testis of rats treated with $\mathrm{GnRH}$-antagonist (GnRH-A)

\begin{tabular}{|c|c|c|c|c|c|}
\hline \multirow[b]{2}{*}{ Treatment } & \multirow[b]{2}{*}{$n$} & \multicolumn{2}{|c|}{ Testis } & \multirow{2}{*}{$\begin{array}{l}\text { Seminiferous } \\
\text { tubular fluid } \\
\left(\mathrm{ng} \mathrm{ml}^{-1}\right)\end{array}$} & \multirow[b]{2}{*}{$\begin{array}{c}\text { Serum } \\
\left(\mathrm{ng} \mathrm{ml}^{-1}\right)\end{array}$} \\
\hline & & $\begin{array}{c}\text { Content } \\
\text { (ng per testis) }\end{array}$ & $\begin{array}{l}\text { Concentration } \\
\quad\left(\mathrm{ng} \mathrm{g}^{-1}\right)\end{array}$ & & \\
\hline Control & 6 & $347 \pm 49$ & $213 \pm 28$ & $54 \pm 14$ & $3.2 \pm 0.3$ \\
\hline \multicolumn{6}{|l|}{$\mathrm{GnRH}-\mathrm{A}\left(\mu \mathrm{g} \mathrm{kg}^{-1}\right)$} \\
\hline 25 & 6 & $153 \pm 21^{a}$ & $103 \pm 14^{a}$ & $39 \pm 4$ & $3.0 \pm 0.3$ \\
\hline 25 plus testosterone & 5 & $14 \pm 2^{\mathrm{ab}}$ & $9 \pm 1^{\mathrm{ab}}$ & $8 \pm 2^{a b}$ & $12.9 \pm 2.8^{\mathrm{ab}}$ \\
\hline 250 & 6 & $8 \pm 4^{a}$ & $7 \pm 3^{a}$ & $8 \pm 2^{\mathrm{a}}$ & $0.1 \pm 0.1^{\mathrm{a}}$ \\
\hline 250 plus testosterone & 6 & $8 \pm 1^{a}$ & $5 \pm 0^{a}$ & $7 \pm 1^{a}$ & $12.3 \pm 1.8^{\mathrm{ab}}$ \\
\hline
\end{tabular}

Values are means \pm SEM.

aSignificantly different from control $(P<0.05)$.

${ }^{b}$ Effect of testosterone implants was significant $(P<0.05)$.

Testosterone concentration in serum, testes and seminiferous tubular fluid was determined by radioimmunoassay in respective ether extracts as described by Huang et al. (1990) using antiserum provided by Radioassay System Laboratory (Carson, CA) with approximately $18 \%$ crossreactivity with DHT. Testicular testosterone was determined in ether extracts of $60-100 \mathrm{mg}$ of decapsulated testicular tissue homogenized in $1 \mathrm{ml}$ phosphatebuffered saline ( $\mathrm{pH}$ 7.4) without chromatography. The sensitivity of testosterone assay was $2.25 \mathrm{pg}$ per tube. The intra- and interassay coefficients of variation were 5 and $12 \%$, respectively.

\section{Measurement of androgen-binding protein}

Androgen-binding protein (ABP) concentrations in serum, interstitial fluid, seminiferous tubular fluid and epididymal cytosol were determined by radioimmunoassay as described by Pogach et al. (1988). The sensitivity of the assay was $30 \mathrm{ng}$ $\mathrm{ml}^{-1}$ with 6 and $11 \%$ inter- and intra-assay coefficients of variation, respectively.

\section{$\left[{ }^{3} H\right] D H T$-binding capacity of androgen-binding protein}

For the measurement of the binding activity of ABP, $50 \mu \mathrm{l}$ of interstitial fluid or seminiferous tubular fluid was diluted with $450 \mu$ l of PBS ( $\mathrm{pH}$ 7.2). The endogenous androgen in these fluids was stripped with activated charcoal $\left(20 \mathrm{mg} \mathrm{mg}^{-1}\right.$ protein) in the cold room $\left(4^{\circ} \mathrm{C}\right)$ overnight. This procedure removed $90-95 \%$ of $\left[{ }^{3} \mathrm{H}\right]$ testosterone in pilot experiments. After the removal of the charcoal by centrifugation $(1500 \mathrm{~g}$ for $30 \mathrm{~min}$, three times), the supernatants were dialysed against $0.2 \mathrm{~mol}$ $\mathrm{NH}_{4}\left(\mathrm{CO}_{3}\right)_{2} 1^{-1}$ overnight at $4^{\circ} \mathrm{C}$. The dialysed materials were subsequently lyophylized and reconstituted in the appropriate

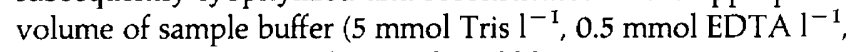
$10 \%$ glycerol and $0.1 \%$ bromophenol blue).

The binding capacity of ABP was determined by measuring its binding with $\left[{ }^{3} \mathrm{H}\right] \mathrm{DHT}$ during steady state electrophoresis (Ritzen et al., 1974). The gels were cut into 50 slices, and the radioactivity of each slice was determined by scintillation counting. Two radioactive peaks (slices 12-16, and slices 18-23) were detected in all samples. The radioactivity of the first peak representing the binding of $\left[{ }^{3} \mathrm{H}\right] \mathrm{DHT}$ by $\mathrm{ABP}$ was used for calculation and the results were expressed as d.p.m $\left[{ }^{3} \mathrm{H}\right] \mathrm{DHT}$ per $\mathrm{ng}$ of radioimmunoactive ABP.

\section{Statistical analysis}

Analysis of variance was used to detect the significance of treatments. When the treatment effects were significant, Scheffe's multiple range test was used to detect the significance among groups.

\section{Results}

\section{Organ weights}

The weights of the testis and epididymis were unaffected after 2 weeks of daily injections of $25 \mu \mathrm{g} \mathrm{GnRH}-\mathrm{A} \mathrm{kg}^{-1}$, with or without subcutaneous testosterone implants (Table 1). Daily injection of $250 \mu \mathrm{g} \mathrm{GnRH}-\mathrm{A} \mathrm{kg}^{-1}$ resulted in a $40 \%$ and $60 \%$ reduction $(P<0.05)$ in the weights of the testis and epididymis, respectively. These changes were prevented by the testosterone implants $(P<0.05)$. The weight of the seminal vesicle was significantly less $(P<0.05)$ in animals receiving either dose of $\mathrm{GnRH}-\mathrm{A}$, but was increased relative to controls $(P<0.05)$ in animals receiving a testosterone implant. The weight of the pituitary gland was not affected in animals in the $25 \mu \mathrm{g} \mathrm{GnRH}-\mathrm{A} \mathrm{kg}^{-1}$ group, but was significantly less than controls in those receiving $250 \mu \mathrm{g} \mathrm{GnRH}-\mathrm{A} \mathrm{kg}^{-1}$ injections $(P<0.05)$.

\section{Hormone concentrations}

Daily injections of 25 or $250 \mu \mathrm{g}$ GnRH-A kg ${ }^{-1}$ suppressed serum FSH concentration of adult rats to 85 and $20 \%$, respectively, of the control value $(P<0.05$, Fig. 1). Testosterone implants decreased serum FSH further in rats given $25 \mu \mathrm{g}$ GnRH-A kg ${ }^{-1}$ injections $(P<0.05)$ but increased those of rats Downloaded from Bioscientifica.com at 04/26/2023 09:53:30AM 


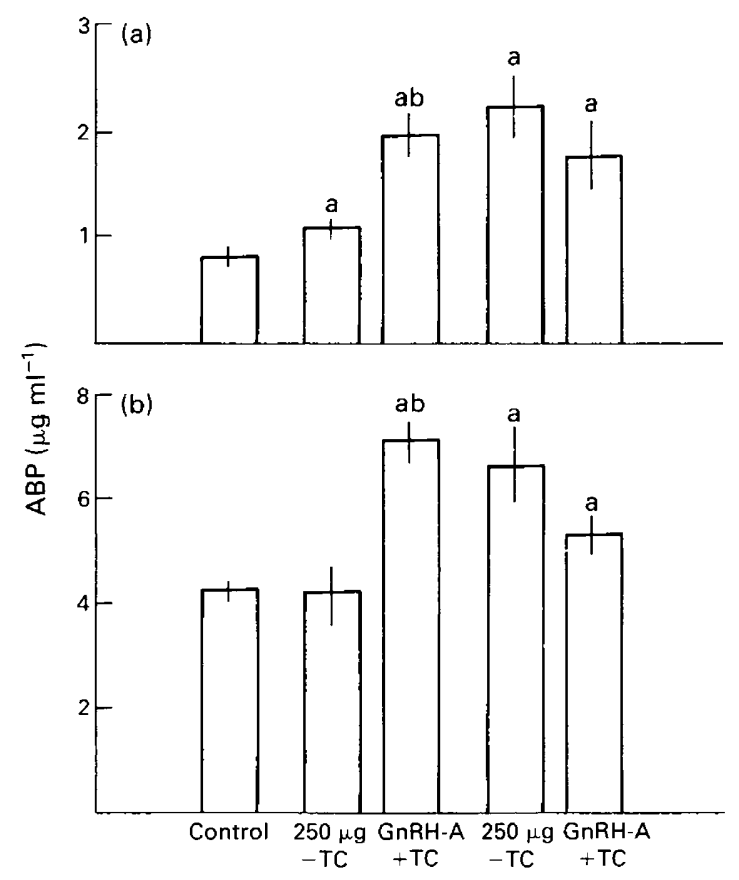

Fig. 2. Concentration of androgen-binding protein (ABP) in (a) interstitial fluid and (b) seminiferous tubular fluid of rats receiving injections of 25 or $250 \mu \mathrm{g}$ of GnRH-antagonist (GNRH-A) kg-1 with (+TC) or without $(-\mathrm{TC})$ testosterone capsules for 2 weeks. Results are

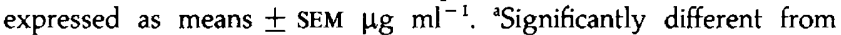
control $(P<0.05)$; beffect of testosterone capsule treatment was significant compared with GnRH-A alone $(P<0.05) . n=5-6$ rats.

in the group receiving $250 \mu \mathrm{g}$ GnRH-A kg ${ }^{-1}(P<0.05)$, to values comparable to that of the $25 \mu \mathrm{g} \mathrm{kg}^{-1}$ group ( $50 \%$ of the control value).

Serum LH was depressed by approximately $60 \%$ in rats given $25 \mu \mathrm{g} \mathrm{GnRH}-\mathrm{A} \mathrm{kg}^{-1}$ injections $(P<0.05)$, and was further decreased when testosterone implants were given $(P<0.05)$. In rats in the $250 \mu \mathrm{g} \mathrm{GnRH}-\mathrm{A} \mathrm{kg}^{-1}$ group, with or without testosterone implants, serum $\mathrm{LH}$ concentrations were at the detection limit of the assay $(P<0.05$, Fig. 1$)$

Injection of $\mathrm{GnRH}-\mathrm{A}$ resulted in a dose-dependent suppression of testosterone in serum, testis and seminiferous tubular fluid $(P<0.01$; Table 2$)$. Testosterone implants further decreased testosterone concentrations in rats given $25 \mu \mathrm{g}$ GnRH- $\mathrm{A} \mathrm{kg}^{-1}$ injections but had no additional effect upon the testosterone profile in rats in the $250 \mu \mathrm{g} \mathrm{GnRH}-\mathrm{A} \mathrm{kg}^{-1}$ group.

\section{Androgen-binding protein}

Androgen-binding protein concentration in interstitial fluid and seminiferous tubular fluid was not affected by daily injections of $25 \mu \mathrm{g}$ GnRH-A kg ${ }^{-1}$, but was significantly increased when testosterone implants were also given $(P<0.05$, Fig. 2). Injections of $250 \mu \mathrm{g} \mathrm{GnRH}-\mathrm{A} \mathrm{kg}^{-1}$ resulted in a significant increase in $\mathrm{ABP}$ concentration in interstitial and seminiferous tubular fluid $(P<0.05)$, but these increments were less pronounced when animals were given testosterone implants.

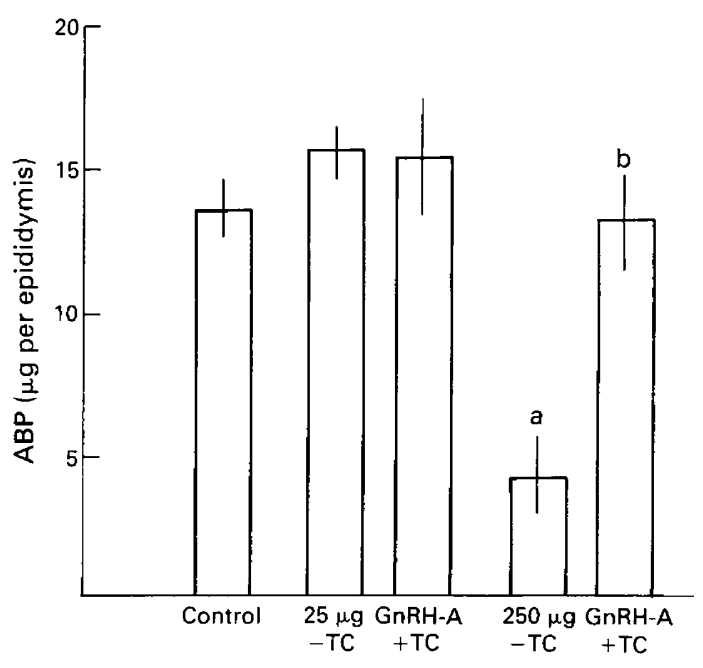

Fig. 3. Epididymal content of androgen-binding protein (ABP) (mean \pm SEM ng per epididymis) of adult rats given 25 or $250 \mu \mathrm{g}$ $\mathrm{GnRH}$-antagonist ( $\mathrm{GnRH}$-A) with $(+\mathrm{TC})$ or without $(-\mathrm{TC})$ testosterone capsules. ${ }^{a}$ Significantly different from control $(P<0.05)$; beffect of testosterone capsule treatment was significant compared with GnRH-A alone $(P<0.05) . n=5-6$ rats.

Table 3. Effects of GnRH-antagonist (GnRH-A) upon the biological activity of androgen-binding protein in rats

\begin{tabular}{lccc}
\hline & $n$ & $\begin{array}{c}\text { Interstitial } \\
\text { testicular } \\
\text { fluid }^{\mathrm{a}}\end{array}$ & $\begin{array}{c}\text { Seminiferous } \\
\text { testicular } \\
\text { fluid }\end{array}$ \\
\hline Treatment & 4 & $252 \pm 23$ & $10.9 \pm 0.9$ \\
$\begin{array}{l}\text { Control } \\
\text { GnRH-A }\left(\mu \mathrm{g} \mathrm{kg}^{-1}\right)\end{array}$ & 4 & $180 \pm 6^{\mathrm{b}}$ & $10.6 \pm 0.8$ \\
$\quad 25$ & 4 & $206 \pm 12^{\mathrm{b}}$ & $13.3 \pm 1.1$ \\
$\quad 25$ plus testosterone & 4 & $120 \pm 8^{\mathrm{b}}$ & $11.1 \pm 0.9$ \\
250 & 4 & $171 \pm 12^{\mathrm{bc}}$ & $13.5 \pm 1.1$ \\
250 plus testosterone & & & \\
\hline
\end{tabular}

'Values expressed as means \pm SEM of c.p.m. $\left[{ }^{3} \mathrm{H}\right]$-dihydrotestosterone ng ${ }^{-1}$ androgen-binding protein.

'Significantly different from control $(P<0.05)$.

'Effect of testosterone capsule implant was significant $(P<0.05)$.

Although $A B P$ concentration per gram of tissue was not affected (data not shown), epididymal ABP content was significantly less in rats given $250 \mu \mathrm{g}$ GnRH-A kg ${ }^{-1}$ injections $(P<0.05)$, but this suppression was prevented by testosterone implants (Fig. 3).

\section{$\left[{ }^{3} H\right] D H T$-binding activity of androgen-binding protein}

The $\left[{ }^{3} \mathrm{H}\right] \mathrm{DHT}$-binding activity of $\mathrm{ABP}$ in seminiferous tubular fluid was not affected by either dose of GnRH-A, with or without testosterone implants, but it was significantly decreased in interstitial fluid following the administration of 25 or $250 \mu \mathrm{g} \mathrm{GnRH}-\mathrm{A} \mathrm{kg}^{-1}(P<0.05$; Table 3$)$. This effect was partially prevented by testosterone implants. 


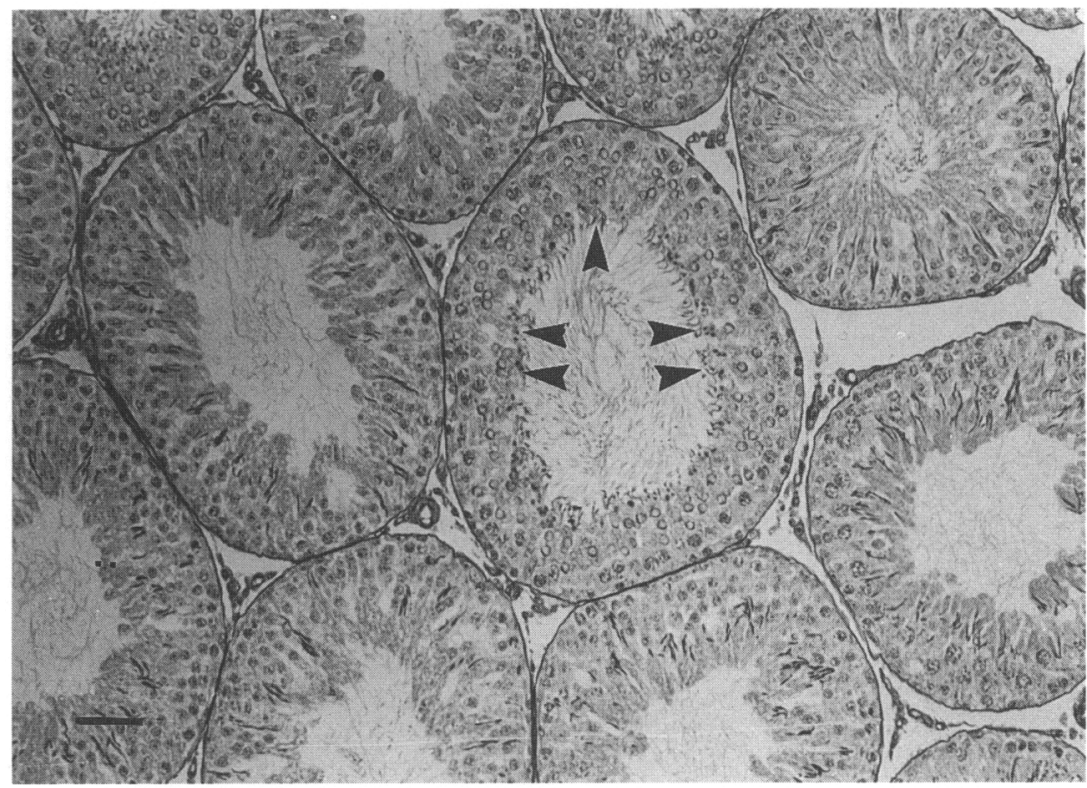

Fig. 4. Photomicrograph of testis of control rat. The presence of step 18-19 spermatids (arrowheads) at the luminal edge of stage VII-VIII epithelium demonstrates the completeness of spermatogenesis. Bar $=10 \mu \mathrm{m}$.

Table 4. The effect of GnRH-antagonist (GnRH-A) on the number of spermatids in intact adult rats

\begin{tabular}{lcccc}
\hline Treatment & $n$ & Step $7^{\mathrm{a}}$ & Step 19 & Step 19/Step 7 \\
\hline Control & 5 & $927 \pm 42$ & $865 \pm 49$ & 0.93 \\
GnRH-A $\left(\mu \mathrm{g} \mathrm{kg}^{-1}\right)$ & & & & \\
$\quad 25$ & 3 & $598 \pm 52^{\mathrm{b}}$ & $556 \pm 54^{\mathrm{b}}$ & 0.93 \\
$\quad 25$ plus testosterone & 3 & $618 \pm 23^{\mathrm{b}}$ & $595 \pm 38^{\mathrm{b}}$ & 0.96 \\
250 & 4 & $460 \pm 87^{\mathrm{b}}$ & $69 \pm 46^{\mathrm{cd}}$ & 0.15 \\
250 plus testosterone & 3 & $561 \pm 58^{\mathrm{b}}$ & $516 \pm 51^{\mathrm{be}}$ & 0.92 \\
\hline
\end{tabular}

\footnotetext{
${ }^{2}$ Values expressed as means \pm SEM per 100 Sertoli cell nucleoli.

${ }^{b} p<0.05$ versus control.

c $P<0.01$ versus control.

${ }^{\mathrm{d}} P<0.01$ versus $25 \mu \mathrm{g}$ GnRH-A kg ' dose.

$\cdot P<0.01$ versus testosterone without implant.
}

\section{Spermatogenesis}

In control animals, the presence of mature spermatids at the luminal edge of stage VII-VIII epithelium demonstrated the completeness of spermatogenesis (Fig. 4). Although complete spermatogenesis was maintained in rats given $25 \mu \mathrm{g} \mathrm{GnRH-A}$ $\mathrm{kg}^{-1}$ injections, the number of step 7 and step 18/19 spermatids was reduced by $35 \%(P<0.05)$ and was not affected by testosterone implants (Table 4). Daily administration of $250 \mu \mathrm{g}$ $\mathrm{GnRH}-\mathrm{A} \mathrm{kg}^{-1}$ resulted in the arrest of spermatogenesis in the majority (4 of 6) of the animals (Fig. 5). The number of step 7 and step 18/19 spermatids was decreased by 65 and $95 \%$, respectively (Table 4). Testosterone implants resulted in the maintenance of complete spermatogenesis in all animals receiving daily injections of $250 \mu \mathrm{g}$ GnRH- $\mathrm{A} \mathrm{kg}^{-1}$, and restored the number of spermatids to approximately $60 \%$ of controls (Fig. 6).
The efficacy of spermatid differentiation, as indicated by the ratio between step 7 and step 19 spermatids, was normal in rats given $25 \mu \mathrm{g} \mathrm{GnRH}-\mathrm{A} \mathrm{kg}^{-1}$ injections; however, in rats receiving $250 \mu \mathrm{g} \mathrm{GnRH}-\mathrm{A}$, less than $15 \%$ of the step 7 spermatids could differentiate to maturity. Exogenous testosterone administration enabled more than $90 \%$ of the step 7 spermatids to develop to maturity in rats receiving the $250 \mu \mathrm{g} \mathrm{kg}^{-1}$ dose of GnRH-A.

\section{Discussion}

The failure of exogenous testosterone alone to maintain or restore a normal number of spermatids in hypophysectomized rats (Huang et al., 1987; Santulli et al., 1990; Huang et al., 1991) demonstrates the importance of pituitary factors for normal 


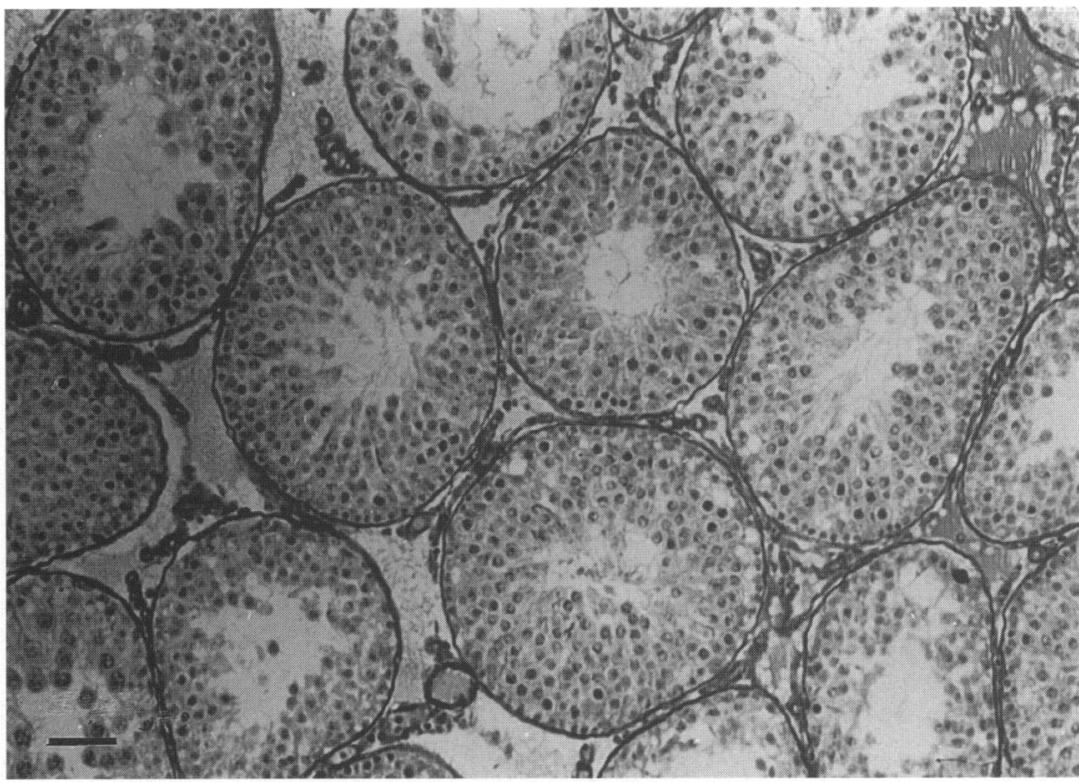

Fig. 5. Photomicrograph of testis of a rat given $250 \mu \mathrm{g} \mathrm{GnRH}$-antagonist $\mathrm{kg}^{-1}$ for 2 weeks. Note the disruption of spermatogenesis and absence of elongated spermatids in all tubules. $\mathrm{Bar}=10 \mu \mathrm{m}$.

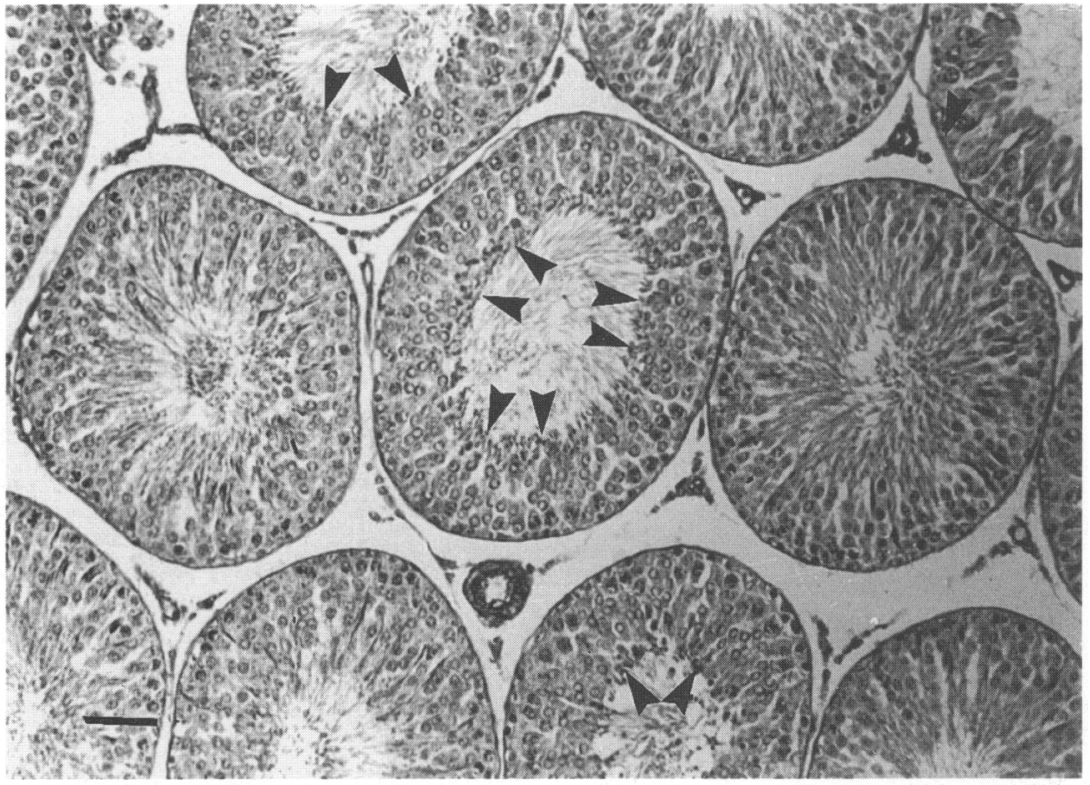

Fig. 6. Photomicrograph of testis of a rat given $250 \mu \mathrm{g} \mathrm{GnRH}$-antagonist $\mathrm{kg}^{-1}$ plus testosterone implant for 2 weeks. Note the presence of elongated spermatids (arrowheads) in all tubules. Bar $=10 \mu \mathrm{m}$.

spermiogenesis. The importance of $\mathrm{FSH}$ for quantitative spermiogenesis has previously been demonstrated in hypophysectomized rats (Bartlett et al., 1989; Huang et al., 1991), but the mechanism by which FSH affects spermatid differentiation remains unknown.

In the current study, despite the marked reduction in the number of spermatids, complete spermiogenesis was maintained in the group of rats receiving the $25 \mu \mathrm{g}$ GnRH-A kg ${ }^{-1}$. However, a drastic reduction of the number of young spermatids was associated with the absence of mature spermatids in stage VII epithelium in rats receiving $250 \mu \mathrm{g} \mathrm{GnRH}-\mathrm{A} \mathrm{kg}^{-1}$.
This result demonstrates that the mechanisms regulating the final maturation of spermatids was impaired by high doses of GnRH-A. This impairment was prevented by the administration of exogenous testosterone. The lack of a relationship between the testicular testosterone content or the concentration of testosterone in seminiferous tubular fluid and the status of spermiogenesis is consistent with the hypothesis that the differentiation of spermatids during the second half of spermiogenesis may involve local mechanisms that are not directly related to testicular testosterone concentration (Huang and Boccabella, 1988). 
It is generally accepted that FSH and testosterone modulate the differentiation of spermatogenic cells through their actions on Sertoli cells (Roberts and Zirkin, 1991). Despite the lack of an unequivocal demonstration of androgen receptor in spermatogenic cells using nuclear exchange assays (Frankel et al., 1989), the presence of assayable testosterone and the binding of radioactive testosterone in spermatids (Sanborn et al., 1975; Frankel et al., 1989), and the recent demonstration of mRNA transcripts of androgen receptor in germ cells (Huang et al., 1992b) suggests that testosterone may affect the differentiation of spermatids directly. However, since spermatids are separated from the androgens in interstitial fluid by Sertoli cells, spermatids must acquire testosterone through Sertoli cells. The presence of immunoactive ABP in Sertoli cell processes surrounding spermatids (Attramadal et al., 1981; Pelliniemi et al., 1981) suggests that Sertoli cell ABP may provide a vehicle for delivering testosterone to spermatids.

The possible importance of ABP in spermiogenesis is suggested by the findings of Huang and Boccabella (1988), who showed that the maintenance of spermiogenesis in intact rats given various doses of exogenous testosterone correlated with the ABP content in testes. In hypophysectomized rats, FSH enhancement of maintenance of spermiogenesis by testosterone was associated with an increase in testicular ABP and testosterone content, and epididymal ABP content (Huang et al., 1991). It was postulated that FSH facilitates the accumulation or distribution of testosterone in the testis and the transport of $\mathrm{ABP}$ to epididymis through the modification of the biochemical properties of ABP (Huang et al., 1991).

An increase in the ABP concentration in seminiferous tubular fluid and interstitial fluid and a decrease in epididymal $A B P$ following high doses of $\mathrm{GnRH}-\mathrm{A}$ have been noted in a previous study (Huang et al., 1992a). It was postulated that a failure in the transport of seminiferous tubular fluid to the epididymis may account for the decrease in epididymal ABP and the accumulation of testicular ABP. This may in turn cause an increased $A B P$ release through the basement membrane of Sertoli cell resulting in the higher $A B P$ concentration in interstitial fluid and serum. These changes may result from the suppression of endogenous testosterone production and serum FSH since both hormones are implicated in the regulation of the bidirectional release of $A B P$, and $\mathrm{FSH}$ may be particularly important in the luminal release of ABP (Mather et al., 1983; Sharpe, 1988; Danzo et al., 1990). The concomitant restoration of serum FSH and epididymal ABP in rats receiving the $250 \mu \mathrm{g} \mathrm{GnRH}-\mathrm{A} \mathrm{kg}^{-1}$ injections and testosterone implants supports the above notion.

Although ABP in seminiferous tubular and interstitial fluid are extracellular products, changes in the concentration or binding capacity of $\mathrm{ABP}$ in these fluids undoubtedly reflect alterations in the ABP status inside Sertoli cells. A decrease in the $\left[{ }^{3} \mathrm{H}\right] \mathrm{DHT}$-binding capacity of $\mathrm{ABP}$ in interstitial fluid tubular fluid suggests that GnRH-A treatment results in the modification of the ABP molecule (Cheng et al., 1986). Such a change could affect the testosterone distribution within Sertoli cells and perhaps its delivery to spermatids, resulting in impaired spermiogenesis. This contention is corroborated by the concomitant restoration of the $\left[{ }^{3} \mathrm{H}\right] \mathrm{DHT}$-binding capacity of $A B P$ in interstitial fluid and the efficacy of spermatid differentiation in rats given the high dose of GnRH-A and testosterone implants. This effect was correlated with the partial maintenance of serum FSH, rather than with the status of testicular testosterone content or concentration of testosterone in seminiferous tubular fluid. Although not determined in this study, maintenance of the bioactive as well as the immunoreactive FSH in the rats receiving GnRH-A and testosterone is likely (Sharma et al., 1990). These results suggest that FSH modulates the final differentiation of spermatids through modification of the biochemical properties of ABP, although effects on other Sertoli cell proteins certainly cannot be excluded.

In conclusion, the present study demonstrated that the preservation of complete spermatogenesis by exogenous testosterone in rats treated with $\mathrm{GnRH}-\mathrm{A}$ was associated with the maintenance of serum FSH and restoration of the $\left[{ }^{3} \mathrm{H}\right] \mathrm{DHT}$ binding activity of $\mathrm{ABP}$ in interstitial fluid, rather than with testicular testosterone distribution. Further work, including the immunocytochemical localization of ABP in the seminiferous epithelium under various experimental conditions, and the hormonal regulation of the post-translational modification of ABP molecules is needed so that the significance of this protein in the endocrine control of spermiogenesis can be understood.

This study was supported by a Merit Review Grant from the Veterans Administration Research Service, and C. R. Bard Endowed Funds. We thank M. J. Karten of the Contraceptive Development Branch, Center for Population Research NICHD for the gift of GnRH antagonist, and A. F. Parlow and the NIADDK Pituitary Hormonal Program for the radioimmunoassay kits used in the measurement of FSH, LH, and ABP. The assistance of the Medical Media Service of the East Orange Veterans Administration Medical Center is gratefully acknowledged.

\section{References}

Attramadal A, Bardin WC, Gunsalus GL, Musto NA and Hansson V (1981) Immunocytochemical localization of androgen binding protein in rat Sertoli and epididymal cells Biology of Reproduction 25 983-988

Bartlett JMS, Weinbauer GF and Neischlag E (1989) Differential effects of FSH and testosterone on the maintenance of spermatogenesis in the adult hypophysectomized rat Journal of Endocrinology 121 49-54

Bhasin S, Fielder TJ and Swerdloff RS (1987) Testosterone selectively increases serum follicle stimulating hormone ( $\mathrm{FSH}$ ) but not luteinizing hormone (LH) in gonadotropin-releasing hormone antagonist treated male rats: evidence for differential regulation of FSH and LH secretion Biology of Reproduction 37 55-59

Cheng CY, Gunsalus GL, Morris ID, Turner TT and Bardin CW (1986) The heterogeneity of rat androgen binding protein (rABP) in the vascular compartment differs from that in the testicular tubular lumen. Further evidence for bidirectional secretion of $r$ ABP Journal of Andrology 7 175-179

Cunningham GR and Huckins C (1979) Persistence of complete spermatogenesis in the presence of low intratesticular concentrations of testosterone Endocrinology 105 177-186

Danzo BJ, Pavlou SN and Anthony HL (1990) Hormonal regulation of androgen binding protein in the rat Endocrinology $1272829-2839$

Frankel AI, Chapman IC and Wright WW (1989) The equivocal presence of nuclear androgen binding proteins in mammalian spermatids and spermatozoa Journal of Steroid Biochemistry 33 71-79

Huang HFS and Boccabella AV (1988) Dissociation of the quantitative and the qualitative effects of the suppression of testicular testosterone upon spermatogenesis Acta Endocrinologica 118 209-217

Huang HFS and Nieschlag E (1986) Suppression of the intratesticular testosterone is associated with quantitative change in spermatogonial populations in intact adult rats Endocrinology 118 619-627

Huang HFS, Marshall GR, Rosenberg R and Nieschlag E (1987) Restoration of spermatogenesis by high levels of testosterone in hypophysectomized rats after long-term regression Acta Endocrinologica 116 433-444

Downloaded from Bioscientifica.com at 04/26/2023 09:53:30AM 
Huang HFS, Pogach LM, Nathan E and Giglio W (1990) Acute and chronic effects of cisplatinum upon testicular function in the rat Joumal of Andrology 11 436-445

Huang HFS, Pogach LM, Nathan E, Giglio W and Seebode J (1991) Synergistic effects of FSH and testosterone upon the maintenance of spermiogenesis in hypophysectomized rats. Relationship with androgen binding protein status Endocrinology 128 3152-3161

Huang HFS, Pogach L, Giglio W, Nathan E and Seebode J (1992a) GnRH-A induced arrest of spermiogenesis is associated with altered $\mathrm{ABP}$ distribution in the testis and epididymis Joumal of Andrology 13 153-159

Huang HFS, Li MT, Qian L and Pogach LM (1992b) The presence of mRNA of androgen receptor and androgen binding protein in germ cells 74th Annual Endocrinology Society Meeting, San Antonio, Texas 300 (abstract)

Leblond CP and Clermont Y (1952) Definition of the stages of the cycle of the seminiferous epithelium in the rat Annals New York Academy of Sciences 55 548-573

Mather JP, Gunsalus G, Musto N, Cheng CY, Parvinen M, Wright W, PerezInfante V, Margioris A, Liotta A, Becker R, Kreiger DT and Bardin CW (1983) The hormonal and cellular control of Sertoli cell secretion Journal of Steroid Biochemistry 19 41-51

Pearse AGE (1968) Histochemistry: Theoretical and Applied Vol. I Edn 3 pp 307322. Little Brown, Boston

Pelliniemi LJ, Dym M, Gunsalus GL, Musto NA and Bardin WC (1981) Immunocytochemical localization of androgen binding protein in the male rat reproductive tract Endocrinology 108 925-931

Pogach LM, Lee Y, Gould S, Giglio W and Huang HFS (1988) Partial prevention of procarbazine induced germinal cell aplasia in rats by sequential GnRH antagonist and testosterone administration Cancer Research 48 4354-4360

Rea MA, Marshall GR, Weinbauer GF and Nieschlag E (1986) Testosterone maintains pituitary and serum FSH and spermatogenesis in gonadotropin releasing hormone antagonist-suppressed rats Journal of Endocrinology 108 101-107

Ritzen EM, French FS, Weddington SC, Nayfeh SN and Hansson V (1974) Steroid binding in polyacrylamide gels: quantitation at steady state conditions Joumal of Biological Chemistry 249 6597-6604

Roberts KP and Zirkin BR (1991) Androgen regulation of spermatogenesis in the rat Annals New York Academy of Sciences 637 90-106

Russell LD and Clermont Y (1977) Degeneration of germ cells in normal, hypophysectomized and hormone treated hypophysectomized rats Anatomical Record 187 3477-3566

Sanborn BM, Steinberger A, Meistrich ML and Steinberger E (1975) Androgen binding sites in testis cell fractions as measured by nuclear exchange assay journal of Steroid Biochemistry 6 1459-1465

Santulli R, Sprando RL, Awoniyi CA, Ewing LL and Zirkin BR (1990) To what extent can spermatogenesis be maintained in the hypophysectomized adult rat testis with exogenously administered testosterone? Endocrinology 126 $95-101$

Sharma OP, Khan SA, Weinbauer GF, Arslan M, and Nieschlag E (1990) Effects of androgens on bioactivity and immunoreactivity of pituitary FSH in GnRH antagonist treated rats Acta Endocrinologica 122 168-174

Sharpe RM (1988) Bidirectional secretion by the Sertoli cell International Joumal of Andrology 8 87-91

Turner TT, Jones CE, Howards SS, Ewing LL, Zegeye B and Gunsalus GL (1984) On the androgen microenvironment of maturing spermatozoa Endocrinology $1151925-1932$

Zirkin BR, Santulli R, Awoniyi CA and Ewing L (1989) Maintenance of advanced spermatogenic cells in the adult rat testis: quantitative relationship to testosterone concentrations within the testis Endocrinology 124 3043-3056 